\title{
Effect of Alccofine and Zeolite on the Properties of Concrete Containing Polypropylrne Granules
}

\author{
Kurendha Geetha, Akula Rajani
}

\begin{abstract}
Reinforced concrete structures are affected by various durability problems during their service life. Innovative materials are required in the field of concrete technology for the better construction of the structure. Keeping in view, the present work has been carried out by replacing the cement partially with mineral admixtures namely, Alccofine and Zeolite in different concentrations and by incorporating Polypropylene granules to the concrete. In the present investigation the specimens were divided into three sets. One made with only OPC as binder i.e. conventional mix, second made with OPC and Alccofine/ Zeolite together i.e. binary mix and, third made with $O P C$, Alccofine and Zeolite together i.e. ternary mix. The varying percentages of Alccofine and Zeolite has been taken as $10 \%$ and $15 \%$ as a replacement of cement and the polypropylene granules has been fixed at constant $1 \%$ for all mix proportions of concrete. The w/c ratio was adopted as 0.45 . DOE method of mix design has been adopted. The compressive strength, flexural strength and tensile strength tests have been conducted after the curing period of 28 and 56 days. Results showed that Concrete with 15\% replacement of cement by Alccofine and $10 \%$ replacement of cement by Zeolite along with 1\% Polypropylene granules had shown significant improvement in various mechanical properties at the age of 56 days. It was also observed that concrete with $15 \%$ replacement of cement by Alccofine along with 1\% Polypropylene granules had shown significant improvement in various mechanical properties at the age of 28 days. Thus, the conjoint presence of Alccofine/Zeolite along with polypropylene granules yields better than concrete without any admix.
\end{abstract}

Keywords: Alccofine, Zeolite, concrete mechanical stability.

\section{INTRODUCTION}

The most widely used man made construction material in the world is concrete, due to its low price, appropriate mechanical and durability characteristics as well as ease of being formed into various shapes and sizes. Despite these advantages, environmental problems are arising from the manufacture of Portland cement as a component of concrete. The cement industry alone is responsible for about $7 \%$ of all $\mathrm{CO} 2$ generated [1]. The production of one tone of cement emits one ton of CO2 in the atmosphere. By the year 2020, the

Revised Manuscript Received on June 08, 2020.

* Correspondence Author

Kurendha Geetha*, Assistant Professor, Department of Civil Engineering, Princeton Instuite of Engineering and Technology for Women, Hyderabad, India. E-mail: geethakurendha4@gmail.com

Akula Rajani, Assistant Professor, Department of Civil Engineering, Princeton Instuite of Engineering and Technology for Women, Hyderabad, India. E-mail: akularajni@gmail.com

(C) The Authors. Published by Blue Eyes Intelligence Engineering and Sciences Publication (BEIESP). This is an open access article under the CC BY-NC-ND license (http://creativecommons.org/licenses/by-nc-nd/4.0/)
CO2 emission will rise by 50\% from the current levels [2]. Many researchers have investigated the effect of mineral admixtures like Alccofine, Zeolite, fly ash, silica fume etc with the partial replacement of cement on properties of concrete. Several researchers have also investigated about the addition of plastic to the concrete and its advantages in concrete applications. Akcaozoglu et al., [3] has studied the unit weight, compressive strength and thermal insulation properties, if the unit weight of concrete increases, the strength of concrete increases. However thermal insulation properties decrease, because of increasing unit weight of concrete. Alccofine is a specially processed product based on high glass content with high reactivity obtained through the process of controlled granulation. It improves workability and fluidity of the mix [4]. Natural Zeolite is a volcanogenic sediment material has a three- dimensional frame structure and is classified as a hydrated aluminosilicate of alkali and alkaline earth cations. The large quantity of reactive $\mathrm{SiO} 2$ and $\mathrm{Al} 2 \mathrm{O} 3$ in Zeolite chemically combines with calcium hydroxide produced by the hydration of cement to form additional C- S-H gel and aluminates, resulting in the improvement of microstructure of hardened cement [5]. Karakurt et al., [6] has investigated the special property of Zeolite such as ion exchange, molecular sieves, a large surface area and catalytic activity, which makes them a preferable material for tremendous industrial applications. Laukaitis et al., [7] has investigated the numerous environmental and economic advantages of utilizing the recycled plastics in the form of granules instead of fibers and strips which would result in considerable energy and cost savings, as compared to the production of strips or fibers out of the plastic granules, it was also established that, porosity of contact zone and adhesion depends on the material, of which fibers are made of and the way they were inserted into the mixture.

\section{EXPERIMENTAL PROGRAM}

\section{A. Materials used}

\section{- Cement}

Ordinary Portland cement (OPC) of 53 grades was used. The physical properties and chemical composition of cement obtained from manufactures is presented in Table I and Table II.

Table I: Physical properties of OPC

\begin{tabular}{l}
\hline \multicolumn{1}{|c|}{ Properties } \\
Result \\
Published By: \\
Blue Eyes Intelligence Engineering \\
\& Sciences Publication \\
C Copyriqht: All rights reserved.
\end{tabular}


Effect of Alccofine and Zeolite on the Properties of Concrete Containing Polypropylrne Granules

\begin{tabular}{|c|c|}
\hline Specific gravity & 3.15 \\
\hline Normal consistency & $33 \%$ \\
\hline Fineness of cement & $0.0075\left(\mathrm{~cm}^{2} / \mathrm{gm}\right)$ \\
\hline Initial setting time & 30 minutes \\
\hline Final setting time & $2-3$ hours \\
\hline
\end{tabular}

Table II: Chemical composition of OPC

\begin{tabular}{|c|c|}
\hline Constituent (wt.) & Percentage (\%) \\
\hline Silicon dioxide & 23.41 \\
\hline Aluminum oxide & 5.05 \\
\hline Ferric oxide & 3.4 \\
\hline Calcium oxide & 59.74 \\
\hline Magnesium oxide & 3.33 \\
\hline Sulphur trioxide & 1.43 \\
\hline Potassium oxide & 0.52 \\
\hline Sodium oxide & 0.31 \\
\hline
\end{tabular}

- Alccofine

Alccofine 1203 used in the present investigation is procured from SN Enterprises Bangalore. The physical and chemical properties of Alccofine are presented in Table III and Table IV respectively.

Table III: Physical properties of Alccofine

\begin{tabular}{|c|c|}
\hline Properties & Result \\
\hline Specific gravity & 2.9 \\
\hline Fineness $\left(\mathrm{cm}^{2} / \mathrm{gm}\right)$ & $>12000$ \\
\hline Bulk density $\left(\mathrm{kg} / \mathrm{m}^{3}\right)$ & $700-900$ \\
\hline
\end{tabular}

Table IV: Chemical composition of Alccofine

\begin{tabular}{|c|c|}
\hline Constituent (wt.) & Percentage (\%) \\
\hline Silicon dioxide & 34.65 \\
\hline Aluminum oxide & 16.42 \\
\hline Ferric oxide & 1.83 \\
\hline Calcium oxide & 62.16 \\
\hline Magnesium oxide & 8.23 \\
\hline Sulphur trioxide & 0.44 \\
\hline
\end{tabular}

- Zeolite

Zeolites are hydrated alumina silicates of alkali and alkali earth cations with a three- dimensional frame structure with uniform pores, channels and cavities. The physical properties and chemical composition of Zeolite are presented in Table V and Table VI respectively.

Table V: Physical properties of Zeolite

\begin{tabular}{|c|c|}
\hline Properties & Result \\
\hline Specific gravity & 2.2 \\
\hline Fineness $\left(\mathrm{cm}^{2} / \mathrm{gm}\right)$ & 11305 \\
\hline Bulk density $\left(\mathrm{kg} / \mathrm{m}^{3}\right)$ & 810 \\
\hline
\end{tabular}

Table VI: Chemical composition of Zeolite

\begin{tabular}{|c|c|}
\hline Constituent (wt.) & Percentage (\%) \\
\hline Silicon dioxide & 77.08 \\
\hline Aluminum oxide & 13.55 \\
\hline Ferric oxide & 1.60 \\
\hline Calcium oxide & 2.38 \\
\hline Magnesium oxide & 1.47 \\
\hline Potassium oxide & 3.88 \\
\hline
\end{tabular}
Sodium oxide
0.12
- Polypropylene Granules (PG)

Polypropylene granules (PG) of plastic waste are procured from plastic company and are occasionally recycled from plastic, it is strong and can usually withstand from higher temperatures. The Polypropylene granules used in the present study is the waste plastic from lunch boxes, bottles etc. The properties of PG are presented in Table VII.

Table VII: Properties of polypropylene granules of plastic

\begin{tabular}{|c|c|}
\multicolumn{2}{|c|}{ waste } \\
\hline Properties & Values \\
\hline Chemical formula & $\mathrm{C}_{3} \mathrm{H}_{6}$ \\
\hline Density $\left(\mathrm{g} / \mathrm{cm}^{3}\right)$ & 0.853 \\
\hline Melting point & 135 to $170^{\circ} \mathrm{C}$ \\
\hline
\end{tabular}

\section{- Fine and Coarse Aggregates}

Locally available river sand was used throughout the investigation as the fine aggregate. The specific gravity of sand was found to be 2.66. From the cumulative percentage passing values of sieve analysis, it is observed that the sand is conforming to grading zone II. Coarse aggregates of size 20 mm maximum size aggregate (MSA) and $10 \mathrm{~mm}$ MSA was used. The specific gravity of MSA was found to be 2.54 and 2.56 respectively.

- Water

Potable Water available in laboratory was used as mixing and curing water.

\section{B. Preparation of concrete specimens}

Cube specimens, cylindrical specimens and prismatic specimens were prepared using ordinary Portland cement (OPC) for different concrete mixes i.e. for conventional mix, mix with varying percentages of Alccofine, Zeolite and polypropylene granules. The details of different concrete mixes used in the present investigation are shown in Table VIII, with the binary and ternary mixes. The concrete mix was prepared at water-cement ratio 0.45 . The mix proportioning of concrete was carried out using Departments of Environments (DOE) method. Table IX shows the mixture proportion of concrete. After 24 hours of casting, the specimens were demoulded and subjected to moist curing for a period of 28 days and 56 days from the day of preparation. After moist curing, the specimens were removed from the curing tank and tested.

Table VIII: Different concrete mixtures

\begin{tabular}{|c|c|c|}
\hline Abbreviation & Concentration & Mix \\
\hline $\mathrm{M}$ & OPC & Conventional \\
\hline M1 & $\begin{array}{c}\text { OPC }+10 \% \text { Alccofine }+1 \% \\
\text { PG }\end{array}$ & \multirow[t]{4}{*}{ Binary } \\
\hline M2 & $\begin{array}{c}\text { OPC+15\%Alccofine+1\% } \\
\text { PG }\end{array}$ & \\
\hline M3 & OPC+10\%Zeolite+1\%PG & \\
\hline M4 & OPC+15\%Zeolite+1\%PG & \\
\hline M5 & $\begin{array}{c}\text { OPC+10\%Alccofine+10\% } \\
\text { Zeolite+1\%PG }\end{array}$ & \\
\hline M6 & $\begin{array}{c}\text { OPC+10\%Alccofine+15\% } \\
\text { Zeolite+1\%PG }\end{array}$ & \\
\hline
\end{tabular}




\begin{tabular}{|c|c|c|}
\hline M7 & $\begin{array}{c}\text { OPC+15\%Alccofine+10\% } \\
\text { Zeolite+1\%PG }\end{array}$ & \multirow{2}{*}{ Ternary } \\
\cline { 1 - 2 } M8 & $\begin{array}{c}\text { OPC+15\%Alccofine+15\% } \\
\text { Zeolite+1\%PG }\end{array}$ & \\
\hline
\end{tabular}

Table IX: Mix proportion of concrete for OPC

\begin{tabular}{|c|c|}
\hline Water-cement ratio & 0.45 \\
\hline Water content $\left(\mathrm{kg} / \mathrm{m}^{3}\right)$ & 190 \\
\hline Binder content $\left(\mathrm{kg} / \mathrm{m}^{3}\right)$ & 422.22 \\
\hline Fine aggregate $\left(\mathrm{kg} / \mathrm{m}^{3}\right)$ & 616.973 \\
\hline Coarse aggregate $\left(\mathrm{kg} / \mathrm{m}^{3}\right)$ & 1145.807 \\
\hline
\end{tabular}

\section{Tests conducted}

\section{- Compressive strength test}

The compressive strength test was conducted at 28 and 56 days in a compression testing machine as per IS: 516:1959 on cube specimens of different concrete mixes [8]. Three cubes were prepared for each concrete mix with varying concentrations of Alccofine, Zeolite and conjointly Alccofine and Zeolite incorporating with 1\% PG and were tested. The average value of compressive strength was obtained.

\section{- Flexural strength test}

Flexural strength test was performed on the prismatic specimens as per IS: 9399:1979 [9]. Three prismatic specimens of each concrete mix were tested and average value of flexural strength was obtained.

\section{- Splitting tensile strength test}

Splitting tensile strength test was conducted in a hydraulically operated compression testing machine after 28 and 56 days of moist curing on the cylindrical specimens of different concrete mixes mentioned in Table VIII. Triplicate cylinder specimens of each concrete mix were prepared and tested for obtaining the average value of splitting tensile strength.

\section{Study on morphology of concrete}

\section{- Scanning electron microscopy (SEM)}

Microanalysis of different concrete mixes was evaluated by scanning electron microscopy. This study was conducted to examine the morphology of concrete. The concrete powder which was collected from $90 \mu$ sieve was sprayed on the stub topped with glue or doublesided tape. Then the sample was pressed with a clean Al-film, to reduce the number of loose grains. The concrete powder is coated with a thin layer of electrically conductive material before scanning i.e. coated with gold by means of high - resolution sputter coater to protect the concrete powder from charging [10]. The stub is placed in the machine and scanned under the electron microscopy of different magnifications.

\section{RESULTS AND DISCUSSIONS}

\section{A. Compressive strength results for binary and ternary mixes}

Compressive strength test was carried out to determine the strength of concrete of different concrete mixes. The results obtained for the binary and ternary concrete mixes have been presented in Table $\mathrm{X}$ respectively.
Table X: Compressive strength results at both the ages of different mixes in $\mathrm{N} / \mathrm{mm}^{2}$

\begin{tabular}{|c|c|c|}
\hline \multirow{2}{*}{ Mixes } & \multicolumn{2}{|c|}{ Age of curing } \\
\cline { 2 - 3 } & 28 days & 56 days \\
\hline M & 36.66 & 37.99 \\
\hline M1 & 38.1 & 52 \\
\hline M2 & 50.88 & 52 \\
\hline M3 & 43.99 & 46.66 \\
\hline M4 & 28.66 & 40.44 \\
\hline M5 & 33.105 & 34.66 \\
\hline M6 & 42.88 & 43.10 \\
\hline M7 & 35.55 & 35.33 \\
\hline M8 & 27.55 & 27.77 \\
\hline
\end{tabular}

From the results presented in table $\mathrm{X}$, it is observed that the compressive strength of concrete increased with increase in Alccofine percentage i.e. from $10 \%$ to $15 \%$ along with $1 \%$ Polypropylene granules curing at the ages 28 to 56 days. Further, it is also observed from table 2, the compressive strength of concrete replaced with 15\% Alccofine and 1\% PG showed higher compressive strength as compared to the conventional concrete and concrete with the binary mixes and ternary mixes. The increase in compressive strength due to increase in Alccofine percentage at constant $1 \%$ of Polypropylene granules and is attributed to the formation of more C-S-H gel due to pozzolanic activity, results in better packing with concrete. The more formation of C-S-H gel was also corroborated from SEM image presented and Fig (b). Further, it is observed from Table X, the compressive strength of ternary mix concrete replaced with $10 \%$ Alccofine and 15\% Zeolite incorporating 1\% PG showed higher compressive strength as compared to the conventional concrete. This may be due to increase in Alccofine percentage and Zeolite percentage at constant 1\% of PG and is attributed to the formation of more C-S-H gel due to the large quantity of reactive $\mathrm{SiO} 2$ and $\mathrm{Al} 2 \mathrm{O} 3$ in Zeolite partly reacts with the $\mathrm{Ca}(\mathrm{OH}) 2$ in the hydration process and also the physical property of high fineness in Alccofine, results in better packing with concrete. Whereas, in mix M8, the concrete strength gets decreased and this may be due to increase in Alccofine percentage and Zeolite percentage at constant 1\% of Polypropylene granules which fills the voids in the concrete through large pore sizes distribution and large porous crystalline fibrous mass, results in the reduction of C-S-H gel and filled with a filler material which is non-cementitious in the concrete. The more formation of pore sizes was also corroborated from SEM image presented in Fig 3.

\section{B. Flexural strength results for binary and ternary mixes}

Flexural strength test was carried out to determine the strength of concrete of different concrete mixes. The results obtained for the binary and ternary concrete mixes have been presented in Table XI respectively.

Table XI: Flexural strength results at both the ages of different mixes in $\mathrm{N} / \mathrm{mm}^{2}$

\begin{tabular}{l}
\multirow{2}{*}{ Mixes } \\
\cline { 2 - 3 }
\end{tabular}




\begin{tabular}{|c|c|c|}
\hline M & 8.3 & 8.9 \\
\hline M1 & 10.9 & 6.9 \\
\hline M2 & 9.28 & 7.935 \\
\hline M3 & 7.375 & 12.8 \\
\hline M4 & 6.97 & 8.5 \\
\hline M5 & 8.2 & 8.9 \\
\hline M6 & 8.4 & 9.9 \\
\hline M7 & 9.7 & 10.4 \\
\hline M8 & 8.6 & 9 \\
\hline
\end{tabular}

From the results presented in table XI, it is observed that the flexural strength of concrete attained more strength with increase in Zeolite percentage i.e. from $0 \%$ to $10 \%$ at the age of 56 days. Further, it is also observed from Table XI, the flexural strength of different concrete mixes increased with the increase in curing age i.e. from 28 days to 56 days.

C. Splitting tensile strength results for binary and ternary mixes

Splitting tensile strength test was carried out to determine the strength of concrete of different concrete mixes. The results obtained for the binary and ternary concrete mixes have been presented in Table XII respectively.

Table XII: Splitting tensile strength results at both the ages of different mixes in $\mathrm{N} / \mathrm{mm}^{2}$

\begin{tabular}{|c|c|c|}
\hline \multirow{2}{*}{ Mixes } & \multicolumn{2}{|c|}{ Age of curing } \\
\cline { 2 - 3 } & 28 days & 56 days \\
\hline M & 3.49 & 3.53 \\
\hline M1 & 3.04 & 3.42 \\
\hline M2 & 3.03 & 3.462 \\
\hline M3 & 2.75 & 2.89 \\
\hline M4 & 2.82 & 3.543 \\
\hline M5 & 2.9 & 3.35 \\
\hline M6 & 3.04 & 3.289 \\
\hline M7 & 2.895 & 3.251 \\
\hline M8 & 3.04 & 3.147 \\
\hline
\end{tabular}

From the results presented in Table XII, it is perceived that the tensile strength of concrete with $1 \%$ PG decreased with increase in varying percentages of Alccofine and Zeolite i.e. from $10 \%$ to $15 \%$ at both the ages i.e. from 28 days to 56 days. Further, it is also observed from Table XII, the tensile strength marginally increased with the age of curing for all concrete mixes irrespective of the replacement percentages of Alccofine, Zeolite and PG at 56 days as compared to that of 28 days. The decrease in tensile strength may be due to to the plastic have a low adhesion to the concrete, results in the less bonding with the surrounding matrix.

\section{Morphological study on concrete}

SEM analysis was used to study the microstructure of hardened concrete. The micrograph shown in Fig 2, concrete with $10 \%$ Alccofine and 1\% Polypropylene granules shows more formation of C-S-H gel as compared to conventional mix shown in Fig 1. Further, the more formation of $\mathrm{Ca}(\mathrm{OH}) 2$ has been observed which are in the form of hexagonal shapes confirmed to Gypsum.

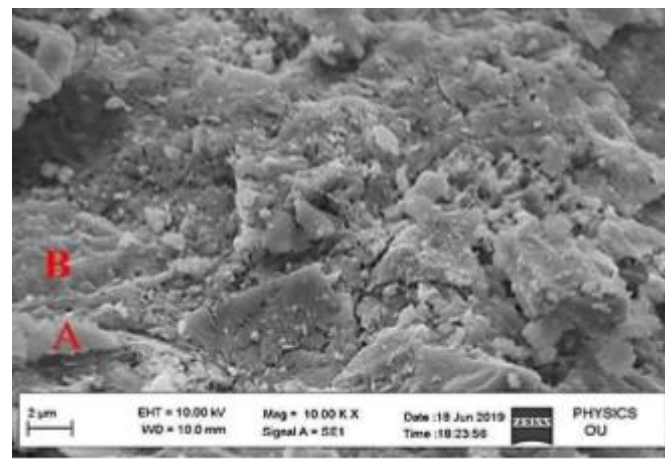

Fig 1: SEM micrograph of OPC concrete mix made at w/b ratio 0.45

A) C-S-H gel B) Gypsum

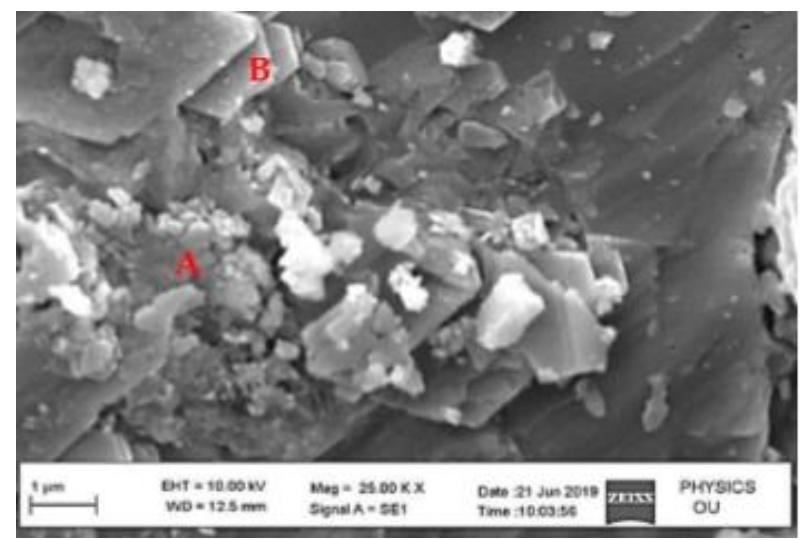

Fig 2: SEM micrograph of concrete with 15\% Alccofine + $1 \%$ PG

A) C-S-H gel B) $\mathrm{Ca}(\mathrm{OH})_{2}$

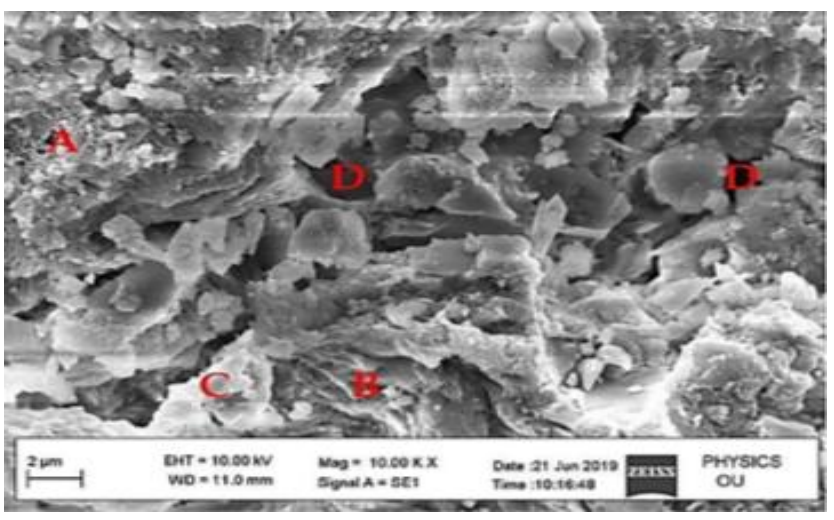

Fig 3: SEM micrograph of concrete with $10 \%$ Alccofine + 15\% Zeolite + 1\% PG

A) Porous crystals B) Gypsum C) C-S-H gel D) Large pore sizes

\section{CONCLUSION}

1. Concrete mixture with $15 \%$ replacement of cement by Alccofine and $10 \%$ replacement of cement by Zeolite along with $1 \%$ Polypropylene granules had shown significant improvement in various mechanical properties at the age of 56 days indicated by $41.8 \%$ increase in compressive strength, $16.8 \%$ increase in flexural strength.

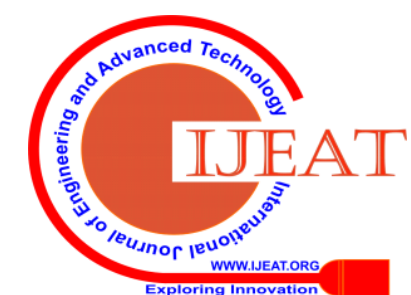


2. The concrete with $15 \%$ Alccofine, 15\% Zeolite along with $1 \%$ Polypropylene granules shows more pore size distribution, results in decrease of strength of the concrete. Development of voids, micro cracks and cohesion less mass due to Polypropylene granules are main reasons for the decrease in the strength of the concrete and also corroborated from scanning electron micrographs.

3 . The tensile strength values of different concrete mixes decreases below the values of the conventional concrete mix and is due to the decrease in the adhesive strength between the surface of the waste plastic granules and cement paste and it may restrict the hydration of cement

\section{REFERENCES}

1. Najimi, M., Sobhani, J., Ahmadi, B., and Shekarchi, M. (2012). “An experimental study on durability properties of concrete containing zeolite as a highly reactive natural pozzolan." Construction and Building Materials, 35, 1023-1033.

2. Parveen, D. S. and B. B. J. (2017). "Experimental study on geopolymer concrete prepared using high-silica RHA incorporating alccofine." Advances in Concrete Construction, 5(August), 345-358.

3. Akçaözoğlu, S., Akçaözoğlu, K., and Atiş, C. D. (2013). "Thermal conductivity, - compressive strength and ultrasonic wave velocity of cementitious composite containing waste PET lightweight aggregate (WPLA)." Composites Part B: Engineering, 45(1), 721- 726.

4. Rajesh Kumar S, Amiya K Samanta, D. K. S. R., and Abstract. (2015). "An experimental study on the mechanical properties of alccofine based high-grade concrete." International Journal of Multidisciplinary Research and Development, 2(10), 218-224.

5. Ahmadi, B., and Shekarchi, M. (2010). "Use of natural zeolite as a supplementary cementitious material." Cement and Concrete Composites, Elsevier Ltd, 32(2), 134-141.

6. Karakurt, C., Kurama, H., and Topçu, I. B. (2010). "Utilization of natural zeolite in aerated concrete production." Cement and Concrete Composites, 32(1), 1-8.

7. Laukaitis, A., Žurauskas, R., and Keriene, J. (2005). "The effect of foam polystyrene granules on cement composite properties." Cement and Concrete Composites, 27(1), 41-47.

8. IS: 516-1959: method of tests for strength of concrete

9. IS: 9399-1979: specification for apparatus for flexural testing of concrete 10) ASTM C1723 - 16, (2016). "Standard Guide For Examination Of Hardened Concrete Using Scanning Electron Microscopy.” ASTM International. Gupta, S., Sharma, S., and Sharma, E. D. (2015). "A Review on Alccofine: A supplementary cementitious material." International Journal of Modern Trends in Engineering and Research, 2(8), 114-119.

\section{AUTHORS PROFILE}

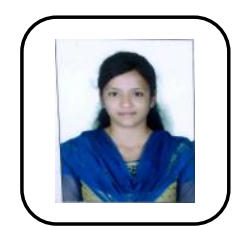

Kurendha Geetha, Assistant professor, Department of Civil Engineering, Princeton instuite of Engineering and Technology for Women, Chowdaryguda Village, Ghatkesar,Telangana-500088., $\quad$ E-mail: geethakurendha4@gmail.com

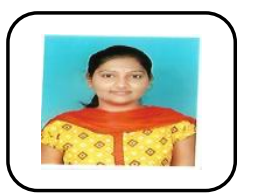

Akula Rajani, Assistant professor, Department of Civil Engineering, Princeton instuite of Engineering and Technology for Women, Chowdaryguda Village, Ghatkesar,Telangana-500088., E-mail: akularajni@gmail.com 